\title{
IL18 Gene
}

National Cancer Institute

\section{Source}

National Cancer Institute. IL18 Gene. NCI Thesaurus. Code C28609.

This gene is involved in the induction and regulation of pro-inflammatory cytokines. 